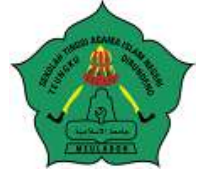

AT-TASYRI' Jurnal Ilmiah Prodi Muamalah

P-ISSN: 2085-2541, E-ISSN: 2715-7865

Volume 12, Nomor 1, Juni 2020

https://ejournal.staindirundeng.ac.id/index.php/Tasyri

\title{
ANALISIS KEPUTUSAN KONSUMEN TERHADAP PENGGUNAAN JASA SEND MEULABOH
}

\author{
Mellyan \\ Dosen Hukum dan Ekonomi Islam STAIN Teungku Dirundeng Meulaboh \\ mellyan@staindirundeng.ac.id \\ Nadya Agustina \\ Mahasiswa Jurusan Syariah Dan Ekonomi Islam STAIN Teungku Dirundeng Meulaboh \\ nadyaagustina206@gmail.com
}

\begin{abstract}
Abstrak
Send Meulaboh ojek online pertama yang beroperasi di Meulaboh. Penelitian ini bertujuan untuk mengetahui analisi keputusan konsumen terhadap penggunaan jasa Send Meulaboh pada mahasiswa/i Sekolah Tinggi Agama Islam Negeri Teungku Dirundeng Meulaboh. Jenis data yang digunakan dalam penelitian ini adalah data kualitatif dengan metode Field Reseach dan Library Research yang bersumber dari data primer dan data sekunder. Teknik pengumpulan data yang dilakukan adalah teknik wawancara, observasi dan menelusuri buku, jurnal, media online maupun artikel terkait. Peneliti melakukan wawancara dengan memberikan beberapa pertanyaan kepada mahasiswa pengguna jasa send Meulaboh. Hasil penelitian menunjukkan sistem control vendor (efisiensi, harga dan kualitas) dan stimulasi pemasaran (produk, harga dan promosi) terlihat sangat berkaitan erat dengan alasan penggunaan jasa Send Meulaboh.
\end{abstract}

Kata kunci: Keputusan Konsumen, Jasa, Send Meulaboh

\begin{abstract}
Send Meulaboh the first online motorcycle taxi to operate in Meulaboh. This study aims to determine the analysis of consumer decisions on the use of Send Meulaboh services on students of the Teungku State Islamic University Dirundeng Meulaboh. The type of data used in this study is qualitative data using the Field Research and Library Research methods which are sourced from primary and secondary data. Data collection techniques used were interviewing, observing and searching books, journals, online media and related articles. Researchers conducted interviews by giving several questions to students who use the Meulaboh send service. The results showed the vendor control system (efficiency, price and quality) and marketing stimulation (product, price and promotion) seemed very closely related to the reasons for using Send Meulaboh services.
\end{abstract}

Keywords: Consumer Decisions, Services, Send Meulaboh 


\section{A. PENDAhuluan}

Aksesibilitas dan interaktivitas internet menghadirkan perubahan dramatis terhadap paradigma pemasaran. Internet mengubah cara organisasi dalam merancang, memproses, memproduksi, memasarkan, serta menyampaikan produk dan jasa. Persaingan yang semakin luas menuntut integrasi dan koordinasi antara sistem informasi, pemasaran, layanan pelanggan, dan berbagai sistem pendukung lainnya. ${ }^{1}$ Internet telah menjadi kebutuhan sehari-hari yang tidak dapat dipisahkan dari perkembangan teknologi dan aktivitas masyarakat. Internet kini semakin mudah diakses tidak hanya melalui komputer namun juga melalui smartphone. Kemudahan dalam mengakses internet menawarkan kecepatan bertukar informasi meskipun berjauhan. Melalui internet, dunia mengenal berbagai hal baru seperti jejaring sosial, berita terupdate, berbelanja online hingga aplikasi yang dapat mengatasi persoalan transportasi atau yang dikenal dengan transportasi online. ${ }^{2}$

Transportasi online semakin dikenal masyarakat sejak GoJek didirikan dan mengekspansi transportasi tradisional. ${ }^{3}$ Sementara di Aceh sendiri, GoJek maupun Grab masih terbatas di wilayah Ibukota Provinsi. Perusahaan transportasi ini terbukti memberikan perubahan yang signifikan terutama bagi kehidupan sosial masyarakat. Bahkan perusahaan tersebut menjadi perusahaan jasa pilihan utama masyarakat terutama wilayah perkotaan.
Jasa Transportasi Online

Tabel 1.1 Penilaian TOP BRAND 2016

Fase 2

Kategori Transportasi Online ${ }^{4}$

\begin{tabular}{cc}
\hline BRAND & TBI 2016 \\
\hline Go-Jek & $80,8 \%$ \\
\hline Grab & $14,7 \%$ \\
\hline Uber & $1,7 \%$ \\
\hline Blu-Jek & $0,7 \%$ \\
\hline $\begin{array}{c}\text { Sumber: } \text { Majalah MARKETING edisi } \\
8 / X V I / \\
\text { AGUSTUS 2016 }\end{array}$
\end{tabular}

Khususnya Kabupaten Aceh Barat, belum tersedia GoJek, Grab, Uber maupun Blu-Jek. Melihat peluang tersebut para pengusaha yang sebagian besar terdiri dari generasi muda berinisiatif mendirikan transportasi online seperti Ho-Jak, Intat, dan Send. Brand jasa transportasi tersebut hadir menjawab kebutuhan masyarakat Kota Meulaboh terhadap jasa transportasi online. Bergerak di bidang jasa, tentu untuk memaksimalkan pendapatan dan kinerja maka perusahaan berupaya maksimal untuk memahami kebutuhan dan keinginan pelangannya. Salah satu variabel terpenting di dalam proses produksi, baik barang maupun jasa adalah besarnya harga jual yang ditetapkan oleh. Kotler dan Amstrong (2001:339) mengatakan bahwa "Harga adalah jumlah uang yang dibebankan untuk sebuah produk atau jasa atau jumlah dari nilai yang ditukar konsumen atas manfaat-manfaat karena memiliki atau menggunakan produk atau jasa tersebut". Harga dan kegiatan promosi merupakan salah satu atribut penting yang dievaluasi oleh konsumen sehingga manajer perusahaan perlu benar-benar memahami peran tersebut dalam

\footnotetext{
${ }^{1}$ Fandi Tjiptono dan Gregorius Chandra, Pemasaran Global konteks Offline dan Online, (Yogyakarta: UPTT STIM YKPN), 2012, hal. 242.

${ }^{2}$ Siti Nur'amna, Skripsi: Analisis Efektivitas Sales Promotion Pada Gojek Dan Grab Serta Pengaruhnya Terhadap Keputusan Pengguna Transportasi Online di Kota Makassar”, (Makassar: UIN, 2018), hal. 1.

${ }^{3} \mathrm{https}$ //inet.detik.com/cyberlife/d-3609781/awal-mula-transportasi-online-menjamur-di-Indonesia diakses pada 29 Juni 2020.

${ }^{4}$ Rafael Billi leksono dan Herwin, Pengaruh Harga Dan Promosi Grab Terhadap Brand Image Yang Mempengaruhi Keputusan Pembelian Konsumen Pengguna Transportasi Berbasis Online, hal. 2.
} 
mempengaruhi sikap konsumen. ${ }^{5}$ Oleh karena itu menarik mengkaji bagaimana keputusan konsumen terhadap penggunaan jasa Send di Kota Meulaboh.

\section{B. KAJIAN PUSTAKA}

Terdapat dua faktor utama yang dapat mempengaruhi konsumen untuk membeli suatu produk atau menggunakan jasa, yaitu faktor eksternal dan internal. (Hurriyati: 2010) Faktor eksternal yang dapat mempengaruhi perilaku konsumen adalah (1) budaya, yaitu keputusan konsumen untuk melakukan pembelian dipengaruhi oleh kebiasaan, pola pikir, kepercayaan dan nilainilai yang berlaku di masyarakat konsumen tersebut tinggal; (2) kelas sosial, sudah menjadi rahasia umum bahwa dalam masyarakat sering terjadi penggolongan kelas sosial, dilihat dari kekuasaan, kekayaan, pengetahuan dan lain-lain dimana hal tersebut juga akan berpengaruh terhadap barang yang akan dikonsumsi; (3) keluarga, keluarga juga dapat berpengaruh terhadap keputusan konsumen untuk membeli sebuah produk karena di situ ada ayah, ibu, paman, bibi, kakek, nenek, yang dapat memberikan kontribusi terhadap keputusan pembelian prroduk. Sedangkan faktor internal yang dapat mempengaruhi keputusan konsumen adalah (1) motivasi, yaitu dorongan dan kebutuhan individu untuk memperoleh kepuasan; (2) pengamatan, yaitu reaksi orientatif terhadap rangsangan-rangsangan, walaupun rangsangan tersebut berupa benda asing, justru asing karena belum pernah mengalami (Swastha dan Handoko: 2014); (3) belajar, perubahan perilaku akibat adanya pengalaman, seperti seseorang akan membeli sebuah produk lebih dari sekali jika produk itu memuaskan; (4) kepribadian dan konsep diri, ada tiga unsur kepribadian yang dapat mempengauhi keputusan konsumen yaitu pengetahuan, perasaan dan naluri; (5) sikap, yaitu kecenderungan untuk bereaksi terhadap produk dalam masalah-masalah yang baik atau kurang baik secara konsekuen (Nickels dalam Swastha: 2010). ${ }^{6}$

Selain itu harga menjadi salah satu penentu paling krusial bagi konsumen dalam memilih produk atau jasa. Dalam artian sempit harga (price) adalah jumlah yang ditagihkan atas suatu produk atau jasa, lebih luas lagi harga adalah jumlah semua nilai yang diberikan oleh pelanggan untuk mendapatkan keuntungan dari memiliki atau menggunakan suatu produk atau jasa. ${ }^{7}$ Harga menjadi faktor utama yang dapat mempengaruhi pilihan seseorang pembeli, harga cukup berperan dalam menentukan pembelian konsumen, untuk itu sebelum menetapkan suatu harga, sebaiknya perusahaan melihat beberapa referensi harga suatu prodak yang dinilai cukup tinggi dalam penjualan. ${ }^{8}$ Menurut Kotler pada dasarnya harga adalah salah satu elemen bauran pemasaran atau marketing mix yang dapat menghasilkan pendapatan. ${ }^{9}$ Menurut Rambat Lupiyoadi dan A. Hamdani, istilah harga dalam bisnis jasa bisa ditemui dengan berbagai sebutan. Universitas atau perguruan tinggi menggunakan SPP (tuition), konsultan

\footnotetext{
${ }^{5}$ Ingrid Panjaitan, Pengaruh Pelayanan Dan Harga Pada Go-Jek Terhadap Kepuasan Konsumen Dengan Minat Sebagai Variabel Moderating. (Jakarta: Media Studi Ekonomi, 2006), hal. 44.

${ }^{6}$ Muhammad Nasrullah, Islamic Branding, Religiusitas dan Keputusan Konsumen Terhadap Produk, Jurnal Hukum Islam (JHI), Volume 13, Nomor 2, Desember 2015, (79-87) Website : http://e-journal.stainpekalongan.ac.id/index.php/jhi, hal. 3 .

${ }^{7}$ Philip Kotler dan Gary Amstrong, Prinsip-prinsip Pemasaran, (Jakarta: Erlangga,2008), hal 345. hal. 128

${ }^{8}$ Ari Setiyaningrum, Jusuf Udaya, dan Efendi, Prinsip-prinsip Pemasaran, (Yogyakarta: Andi, 2015),

${ }^{9}$ Phillip Kotler dan Kevin Lane Keller, Manajemen Pemasaran, Edisi 13 Jilid 2, (Jakarta: Erlangga, 2009), hal. 67.
} 
professional menggunakan istilah fee, bank menggunakan istilah service charge, jasa jalan tol atau jasa angkutan menggunakan istilah tarif, pialang menggunakan istilah komisi, apartemen menggunakan istilah sewa, asuransi menggunakan istilah premi, dan sebagainya. ${ }^{10}$

Harga memiliki dua peranan utama dalam proses pengambilan keputusan para pembeli, yaitu peranan alokasi dan peranan informasi:

a. Peranan alokasi dari harga, yaitu fungsi harga dalam membantu para pembeli untuk memutuskan cara memperoleh manfaat atau utilitas tertinggi yang diharapkan berdasarkan daya belinya. Dengan demikian, adanya harga dapat membantu para pembeli untuk memutuskan cara mengalokasikan daya belinya pada berbagai jenis barang dan jasa. Pembeli membandingkan harga dari berbagai alternatif yang tersedia, kemudian memutuskan alokasi dana yang dikehendaki.

b. Peranan informasi dari harga, yaitu fungsi harga dalam mengedukasi konsumen mengenai faktor-faktor produk, seperti kualitas. Hal ini terutama bermanfaat dalam situasi Ketika pembeli mengalami kesulitan untuk menilai faktor produk atau manfaatnya secara objektif. Persepsi yang sering berlaku adalah bahwa harga yang mahal mencerminkan kualitas yang tinggi. ${ }^{11}$

Menurut Kamus Besar Bahasa Indonesia (KBBI), promosi adalah perkenalan dalam rangka memajukan usaha dagang. ${ }^{12}$
Promosi merupakan salah satu jenis komunikasi yang sering dipakai oleh pemasar. Sebagai salah satu elemen bauran promosi, promosi penjualan merupakan unsur penting dalam kegiatan promosi produk. Definisi promosi penjualan menurut American Marketing Association (AMA) yang dikutip dari bukunya Sustina menunjukkan bahwa promosi merupakan upaya pemasaran yang bersifat media dan non media untuk merangsang coba-coba dari konsumen, meningkatkan permintaan dari konsumen atau untuk memperbaiki kualitas produk. ${ }^{13}$ Menurut Tjiptono, promosi pada hakekatnya adalah suatu komunikasi pemasaran, artinya aktifitas pemasaran yang berusaha menyebarkan informasi, mempengaruhi atau membujuk, dan mengingatkan pasar sasaran atas perusahaan dan produknya agar bersedia menerima, membeli dan loyal pada produk yang ditawarkan perusahaan yang bersangkutan. ${ }^{14}$

Sebaik apapun mutu sebuah produk, semenarik apapun bentuk rupanya atau sebesar apapun manfaatnya, jika tidak ada orang yang mengetahui tentang keberadaannya, maka mustahil produk tersebut dibeli. Produk berkualitas dengan harga yang sesuai jka tidak dikenal oleh konsumen maka produk tersebut tidak akan berhasil di pasar. Sarana dan prasarana yang dibutuhkan secara efektif agar informasi mengenai hadirnya sebuah produk, dapat sampai kepada masyarakat atau konsumen. Upaya untuk mengenalkan produk itu kepada konsumen merupakan awal dari kegiatan

\footnotetext{
${ }^{10}$ Rambat Lupiyoadi dan A. Hamdani. Manajemen Pemasaran Jasa, Salemba Empat, 2006, hal. 98.

${ }^{11}$ Rambat Lupiyoadi dan A. Hamdani. Manajemen Pemasaran Jasa, Salemba Empat, 2006, hal. 152.

${ }^{12}$ Pusat Bahasa Departement Pendidikan Nasional, Kamus Umum Bahasa Indonesia, (Jakarta: Balai Pustaka, 2005), hal. 898.

${ }^{13}$ Sustina, Perilaku Konsumen Dan Komunikasi Pemasaran, (Bandung: PT. Remaja Rosdakarya, 2003), hal. 299.

${ }^{14}$ Fandy Tjiptono, Strategi Pamasaran Edisi Ketiga Cetakan Pertama. (Yogyakarta: Andi Offset, 2001), hal. 219.
} 
promosi. ${ }^{15}$ Kepuasan pelanggan sangatlah penting dipertahankan untuk mempertahankan loyalitas pelanggan, agar pelanggan tetap setia membeli produk atau jasa. Menurut KBBI, kepuasan diartikan sebagai perasaan senang yang diperoleh melalui pengorbanan. ${ }^{16}$ Lebih lanjut terdapat beberapa definisi mengenai kepuasan pelanggan yang dikemukakan oleh para ahli, antara lain; Kotler mendefinisikan. ${ }^{17}$ Kepuasan diartikan sebagai perasaan senang atau kecewa seseorang yang timbul karena membandingkan kinerja yang dipersepsikan (kenyataan yang dialami) terhadap ekspektasi (harapan) mereka. J. Paul Peter dan Jerry C. Olson dalam Usmara mendefinisikan kepuasan atau ketidakpuasan merupakan perbandingan antara harapan kinerja sebelum membeli dan persepsi kinerja yang diterima konsumen setelah membeli. ${ }^{18}$ Jika harapan sebelum membeli lebih besar dari barang/jasa yang diterima setelah membeli, maka dikatakan konsumen mengalami ketidakpuasan. Sebaliknya, jika harapan kinerja sebelum membeli lebih kecil dari persepsi kinerja sebelum membeli maka konsumen mengalami kepuasan.

Oliver dalam Husain Umar, mendefinisikan kepuasan pelanggan sebagai evaluasi purnabeli, di mana persepsi terhadap kinerja produk/jasa yang dipilih memenuhi atau melebihi harapan sebelum pembelian. ${ }^{19}$ Ini artinya apabila persepsi terhadap kinerja tidak dapat memenuhi harapan, maka yang terjadi adalah ketidakpuasan. Sementara Crosby mendefinisikan, "Dissatisfaction with the final product or service of an organization is called trouble with quality". ${ }^{20}$ Dengan demikian, ketidakpuasan terhadap suatu produk dapat menyebabkan masalah dengan kualitas produk atau layanan yang diberikan.

Dari beberapa pengertian kepuasan tersebut, maka dapat diasumsikan bahwa kepuasan adalah perasaan senang atau kecewa yang dimiliki seseorang sebagai hasil perbandingan antara kinerja yang dipersepsikan (kenyataan yang dialami) dengan harapan. Memuaskan kebutuhan pelanggan adalah keinginan setiap produsen/lembaga penyedia layanan jasa. Selain menjadi faktor penting bagi kelangsungan hidup lembaga tersebut, memuaskan kebutuhan pelanggan dapat meningkatkan keunggulan dalam persaingan. Pelanggan yang puas terhadap produk/jasa pelayanan cenderung untuk membeli kembali dan mengajak calon pelanggan baru untuk menggunakan jasa yang telah mereka rasakan kepuasan kinerja pelayanannya.

\section{Penelitian Terdahulu}

Penelitian yang dilakukan oleh Ingrid Panjaitan (2016), dalam jurnalnya yang berjudul "Pengaruh Pelayanan dan Harga pada Go-Jek Terhadap Kepuasan Konsumen dengan Minat sebagai Variabel Moderating (Study Kasus Pada Mahasiswa Universitas 17 Agustus 1945 Jakarta).” Dengan alat analisa Analisis yang digunakan : uji statistik, hasil penelitian menunjukkan bahwa kualitas pelayanan berpengaruh secara signifikan terhadap kepuasann pelanggan, sedangkan variabel harga tidak berpengaruh secara signifikan terhadap kepuasan pelanggan, variabel kualitas pelayanan terhadap kepuasan pelanggan dengan minat sebagai variabel

\footnotetext{
${ }^{15}$ Basu Swastha dan Irawan, Manajemen Pemasaran Modern. (Yogyakarta: Liberty, 2003), hal. 37.

${ }^{16}$ Kamus BesarBahasa Indonesia, (Jakarta: Gramedia, 2008), Ed. IV, Cet. I, hal. 1110

${ }^{17}$ Philip Kotler, Marketing Management: Analysis, Planning, Implementation and Control, (New Jersey: Prentice-Hall Inc, 1997), Ninth Edition, hal. 40

${ }^{18}$ A. Usmara, Strategi Baru Manajemen Pemasaran, (Jogjakarta: Amara Books, 2003), Cet. I, hal. 123

${ }^{19}$ Husain Umar, Metode Riset Perilaku Konsumen Jasa (Jakarta: Ghalia Indonesia, 2003), hal. 14

${ }^{20}$ Philip B. Crosby, Quality Without Tears, (Singapore: McGraw Hill, 1986), hal. 1.
} 
moderating berpengaruh signifikan dan pengaruh harg terhadap kepuasan pelanggan denagn minat beli sebagai variabel moderating juga berpengaruh positif.

Selanjutnya penelitian yang dilakukan oleh Rifaldi, Kadunci dan Sulistyowati (2016), "Pengaruh Kualitas Pelayanan Transportasi Online Gojek Terhadap Kepuasan Pelanggan pada Mahasiswa/i Administrasi Niaga Politeknik Negeri Jakarta". Penelitian ini menggunakan dua variabel, yaitu variabel kualitas pelayanan sebagai variabel independent (bebas) dengan menggunakan lima indikator penelitian, yaitu bukti tampilan (Tangibles), Kehandalan (Reability), Daya tanggap (Responsiveness), Jaminan (Assurance), dan Empati (Emphaty). Dan variabel kepuasan pelanggan sebagai variabel dependent (terikat) dengan menggunakan lima indikator penelitian, yaitu Kualitas Produk, Kualitas Pelayanan, Emosional, Harga, dan Biaya. Persamaan regresi pada penelitian ini adalah $\mathrm{Y}=31,786$ $+0,672 \mathrm{X}$. Berdasarkan hasil analisis korelasi sederhana didapatkan korelasi yakni 0,641 yang berarti terjadi hubungan yang sedang dengan hubungan yang positif karena nilai $\mathrm{R}$ positif. Sedangkan berdasarkan hasil indeks determinasi, presentase pengaruh kualitas pelayanan terhadap kepuasan pelanggan sebesar $41,1 \%$ yang berarti menunjukan hubungan yang sangat kuat.

Selanjutya penelitian yang dilakukan oleh Slaudiya Anjani Septi Damayanti, "Transportasi Berbasis Aplikasi Online: GoJek Sebagai Sarana Transportasi Masyarakat Kota Surabaya". Teori yang digunakan yaitu Tindakan Sosial Max Weber. Informan dalam penelitian ini berjumlah sepuluh pengguna Go-Jek. Penentuan informan dalam penelitian ini menggunakan metode purposive. Pengumpulan data dalam penelitian ini adalah wawancara mendalam dan observasi tidak langsung.
Hasil yang ditemukan dalam penelitian ini antara lain: 1) Tindakan sosial yang dilakukan oleh pengguna adalah rasional instrumental dan afeksi; 2) Tindakan afeksi juga muncul dari pihak keluarga untuk menyarankan dan menentukan transportasi yang tepat; 3) Transportasi berbasis aplikasi online, juga menyediakan jasa layanan memesan makanan, pengantaran barang dan belanja yang dapat dimanfaatkan oleh ibu-ibu rumah tangga ataupun wirausaha rumahan.

Kemudian terdapat penelitian yang dilakukan oleh Berto Mulia Wibawa, Yani Rahmawati, Mathias Rainaldo (2018), "Analisis Industri Bisnis Jasa Online Ride Sharing di Indonesia". Penelitian ini menggunakan metode deskriptif-eksploratif dalam mengidentifikasi Porter's Five Forces sebagai tools dalam analisis industri. Pengumpulan data menggunakan metode ghost interview kepada pengemudi terpilih. Kesimpulan dari penelitian ini adalah industri online-ride sharing di Indonesia cukup menarik untuk dikembangkan di masa depan karena jumlah pelanggan yang belum mencapai titik maksimal, terlebih industri ini dapat menawarkan diferensiasi produk yang sangat bervariasi.

Penelitian yang dilakukan oleh Jifly Kandoli (2019), “Analisa Pengaruh Promosi, Dan Kualitas Layanan Terhadap Keputusan Penggunaan Taxi Online Go-Car Oleh Mahasiswa Feb Unsrat" .Metode yang digunakan adalah regresi linear berganda. Hasil penelitian ini menunjukan secara simultan promosi dan kualitas layanan berpengaruh terhadap keputusan penggunaan taxi online Go-Car, dan secara persial promosi dan kualitas layanan berpengaruh positif signifikan. Sebaiknya untuk bisa dapat bertahan dalam persaingan, PT Go-Jek Indonesia kiranya selalu memberikan promosi - promosi yang menarik bagi para pengguna jasa transportasi online Go-Car khususnya 
mahasiswa Feb Unsrat. Dari kelima penelitian tersebut, memiliki perbedaan dengan penelitian yang penulis lakukan, karena penelitian ini menggunakan analisis keputusan konsumen terhadap penggunaan jasa transportasi ojek online yang berada di Meulaboh, Aceh Barat yaitu Send Meulaboh yang didirikan oleh Pemuda Aceh.

\section{DATA DAN METODOLOGI}

Sesuai dengan tujuan penelitian untuk mengetahui dan melakukan Analisa terhadap penggunaan jasa Send Meulaboh pada mahasiswa/i Sekolah Tinggi Agama Islam Negeri Teungku Dirundeng Meulaboh (STAIN TDM). Penelitian dilakukan dengan metode kualitatif dengan pendekatan deskritif berdasarkan hasil wawancara dengan mahasiswa/i STAIN-TDM Prodi Perbankan Syariah angkatan 2016. Jenis data yang digunakan dalam penelitian ini adalah data kualitatif yang bersumber dari data primer dan data sekunder. Data primer merupakan data yang diperoleh secara langsung dari hasil wawancara peneliti dengan Mahasiswa/i Sekolah Tinggi Agama Islam Negeri Teungku Dirundeng Meulaboh dengan tahun angkatan 2016 prodi Perbankan Syariah Unit B yang telah menggunakan jasa Send. Sedangkan data sekunder merupakan data yang peneliti peroleh dengan cara melakukan studi pustaka yaitu penelusuran melalui buku, jurnal, artikel, dan dari website internet lainnya.

Teknik pengumpulan data yang dilakukan adalah teknik wawancara. Disini peneliti melakukan wawancara dengan memberikan beberapa pertanyaan kepada pengguna jasa send. Proses analisis data dalam penelitian ini mencatat hasil wawancara, mengumpulkan, mencari makna dan menyimpulkan isi dari wawancara dan bahan pendukung lainnya dari sumber seunder yang kemudian di reduksi dan dianalisis.

\section{HASIL DAN PEMBAHASAN}

1. Gambaran Umum Send Meulaboh Send merupakan ojek online pertama yang beroperasi di Meulaboh. Send mulanya digunakan untuk layanan pesan antar makanan mudah dan cepat. Saat ini, Send Meulaboh tidak hanya melayani pesan antar makanan, namun juga melayani jasa antarjemput harian maupun bulanan. Selain murah juga dapat dipercaya dan aman. Send mematok harga sebesar Rp 8.000 khusus Area Kota Meulaboh dan di luar area Meulaboh, berada di kisaran harga lebih dari Rp. 10.000. Sampai Juni 2020, Send Meulaboh belum menggunakan aplikasi khusus, usaha online Ride tersebut masih menggunakan Instagram untuk menawarkan jasa kepada konsumen.

Di Instagram Send Meulaboh, tertera informasi penting mengenai layanan ojek online tersebut. Di "menu" Layanan Kami, Send Meulaboh menawarkan beberapa variasi jasa, yaitu Send Ride-layanan antar jemput penumpang, Send Food-layanan Pesan Antar Makanan, Send Market-layanan pesan antar belanjaan supermarket atau pasar tradisional, dan Send Package-layanan antar paket dalam kota. Melalui sorotan Instagram, informasi tersebut dapat dilihat oleh calon ataupun para Jasa Send, selain itu juga terdapat informasi mengenai contoh pemesanan, harga dan narahubung yang cukup lengkap dan jelas. Untuk lebih jelas dapat dilihat dari gambar di bawah ini: 
Gambar 1.1

Informasi Jasa Layanan Send Meulaboh

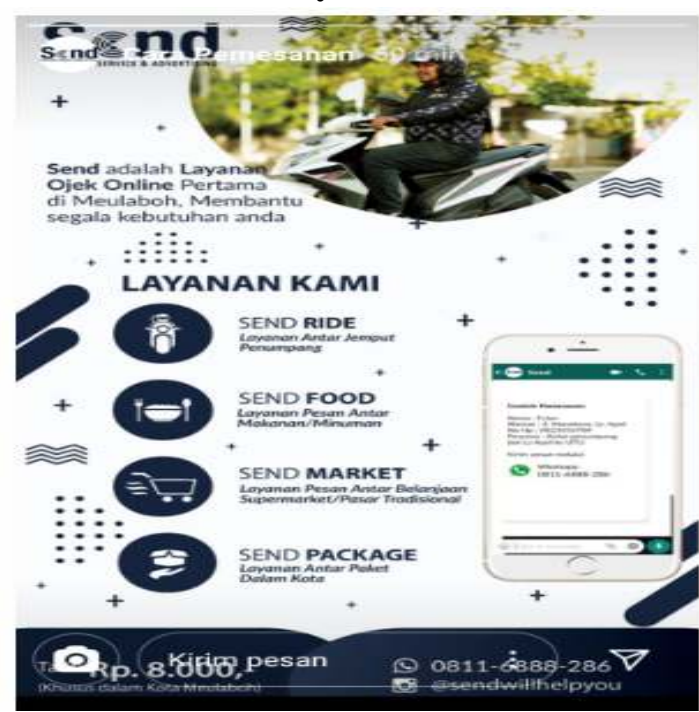

Sumber: Instagram Send Meulaboh

Selain menggunakan Instagram, Send Meulaboh juga menggunakan media sosial lainnya yaitu Whatsapp. Di dalam feed Instagram, perusahaan ojek online dengan tagline Send will hep you ini tertera informasi untuk menggunakan pemesanan

Whatsapp, yaitu dengan empat cara mudah, pertama menyimpan nomor kontak Send Meulaboh, Membuka kontak Whatsapp, kemudian klik nama Send untuk melihat profil dan klik katalog untuk melihat daftar menu. Cara mudah dan sederhana tersebut ditawarkan oleh Send Meulaboh kepada konsumen.

Selain itu, Instagram Send Meulaboh sampai 30 Juni 2020 telah memiliki 2.925 pengikut dengan 404 postingan. Banyaknya jumlah postingan membuktikan keseriusan manajemen Send Meulaboh dalam menggunakan media sosial untuk mempromosikan serta menawarkan produk.
Send Meulaboh juga menjaga konsistensi penggunaan warna biru dan putih untuk feed Instagram mereka. Selain terlihat lebih professional, hal tersebut juga menjadi ciri khas Send Meulaboh.

\section{Analisis Terhadap Penggunaan Jasa Send Meulaboh \\ Keputusan membeli secara online} dipengaruhi oleh beberapa hal, (Deavaj et al. 2003) yaitu (1) Efisiensi untuk pencarian (waktu cepat, mudah dalam penggunaan, dan usaha pencarian mudah), (2) value (harga bersaing dan kualitas baik), dan (3) interaksi (informasi, keamanan, load time, dan navigasi). Kemudahan dalam mencari sangat diperlukan untuk menghemat waktu. Sehingga efisiensi meningkat. ${ }^{21}$ Untuk lebih detail, dapat dilihat dari tabel di bawah ini $^{22}$ :

Gambar 1.2. Model Faktor-Faktor yang mempengaruhi keputusan membeli/ menggunakan jasa Secara Online



E. KEPUTUSAN MEMBELI ATAU MENGGUNAKAN JASA

Jika menelaah tabel di atas, dapat diamati bahwa Send Meulaboh hadir disebabkan oleh beberapa hal, yaitu faktor psikologi yang terdiri dari motivasi, kepribadian, belajar dan sikap. Motivasi hadir ketika di Indonesia, bahkan di Aceh, muncul aplikasi transportasi online yang menjawab

\footnotetext{
${ }^{21}$ Yohanes Suhari, Jurnal Keputusan Membeli Secar Online dan Faktor-Faktor yang mempengaruhinya, Jurnal Teknologi Informasi DINAMIK Volume XIII, No.2, Juli 2008 : 140-146, hal. 4.

${ }^{22}$ Yohanes Suhari, Jurnal Keputusan Membeli Secar Online dan, ..., hal. 8.
} 
kebutuhan masyarakat modern, sedangkan Kota Meulaboh belum memiliki transportasi serupa, sehingga kemunculan Send Meulaboh menjadi pilihan dan disambut dengan baik oleh masyarakat. Kepribadian, belajar dan sikap masyarakat juga mempengaruhi keputusan menggunakan jasa send, keingintahuan dan kepraktisan menjadikan Send Meulaboh semakin diminati.

Selanjutnya lingkungan Sosial dan Budaya, masyarakat Meulaboh khususnya yang berada di daerah perkotaan menginginkan kemudahan dan keparktisan, hal tersebut ditawarkan oleh Send Meulaboh, sehingga usaha online ride tersebut cukup berkembang. Chief Executive Officer (Ceo), Imam Mustafa mendirikan Send Meulaboh dengan melihat peluang dan potensi ojek online di Meulaboh. Saat launching, Send Meulaboh hanya memiliki 20 pelanggan, kini telah berkembang lebih dari 3000 pengguna. ${ }^{23}$

Sedangkan untuk menelaah sistim Vendor dan Stimulasi Pemasaran dapat diamati dari hasil wawancara dengan pengguna jasa Send Meulaboh dari STAIN Teungku Dirundeng Meulaboh. Berdasarkan hasil wawancara dengan Ilham Saputra, awal mula ketertarikan menggunakan jasa Send Meulaboh karena kepraktisan yang diberikan. Ilham mengaku puas dengan pelayanan yang diberikan. Harga menurut Ilham sangat berpengaruh karena menjadi faktor utama ketika ingin menggunakan jasa Send. Karena harga yang relative murah dan cocok dengan kantong mahasiswa, ia memutuskan menggunakan Send Meulaboh. Selain itu promosi yang gencar dilakukan di media sosial juga mempengaruhi generasi muda untuk menggunakan Send Meulaboh. ${ }^{24}$

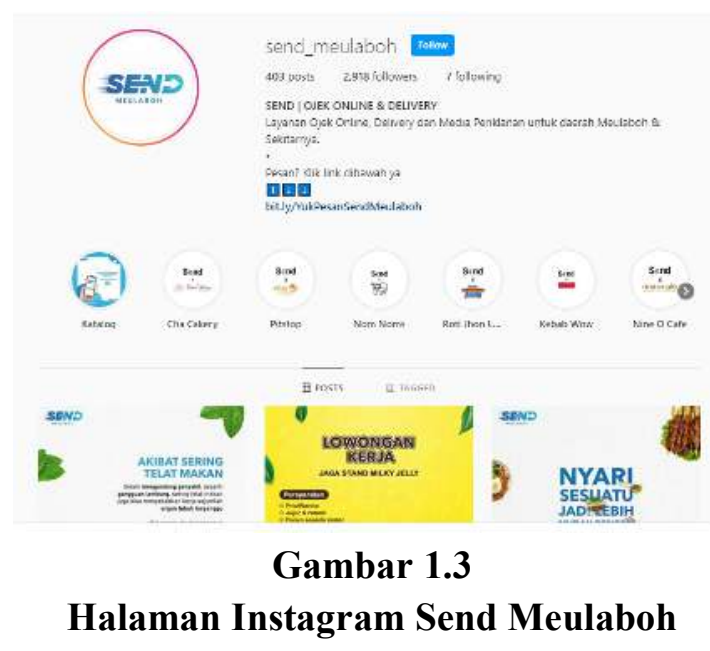

Saidah, mahasiswa Prodi Perbankan Syariah pada jurusan Syariah dan Ekonomi Islam STAIN TDM menyatakan sangat puas dalam hal pelayanan yang diberikan oleh pihak Send Meulaboh. Menurutnya, Send merespon dengan baik dan sopan ketika ia mengorder makanan. Padahal saat itu ia memesan cukup banyak makanan dengan berbagai variasi, sehingga mengharuskan driver Send Meulaboh mencari kebutuhan konsumen di beberapa lokasi berbeda, namun Send tetap melayani dengan baik. Demikian pula dengan harga yang menurut saidah sangat berpengaruh terhadap keputusan ia menggunakan jasa Send. Menurutnya, harga yang ditawarkan Send Meulaboh sangat terjangkau, terutama terjangkau anak kost, Send Meulaboh juga sangat membantunya ketika membutuhkan makanan anatu belanjaan, namun cuaca sedang hujan atau karena sedang malas keluar rumah. Ia mengaku sangat terbantu untuk membeli keperluan tanpa harus membuang tenaga dan waktu. Jasa Send menurut Saidah sangat efesien dan efektif untuk para milenial. ${ }^{25}$

Kualitas pelayanan merupakan tingkat keunggulan (excellence) yang diharapkan dan

\footnotetext{
${ }^{23} \mathrm{https}$ //www.beacukai.go.id/berita/hadiri-hari-pers-nasional-bc-meulaboh.html diakses 29 Juni 2020

${ }^{24}$ Wawancara dengan Ilham Saputra, pada tanggal 10 Januuari 2020.

${ }^{25}$ Wawancara dengan Saidah, pada tanggal 10 Januuari 2020.
} 
pengendalian atas keunggulan tersebut untuk memenuhi keinginan pelanggan (Tjiptono, 2007). Perusahaan yang memberikan komitmen pada kualitas dan secara konsisten memberikan kualitas pelayanan akan menikmati keunggulan persaingan sehingga perusahaan dapat dengan mudah meningkatkan loyalitas dan sukses membangun hubungan dengan pelanggan. ${ }^{26}$

Berdasarkan wawancara dengan Nedy Iswandi, harga menurutnya tidak begitu berpengaruh terhadap keputusan menggunakan jasa Send karena untuk seputaran Meulaboh hanya dihargai Rp. 8.000, faktor lain yang berpengaruh adalah Promosi. Menurut Nedy, promosi cukup signifikan mempengaruhinya menggunakan jasa Send karena iklan yang ditawarkan cukup menarik keinginan untuk memesan Send. Iklan yang diberikan pihak Send seperti gambar makanan, baju atau tas yang dijual disekitar Meulaboh sangat menggiurkan. ${ }^{27}$

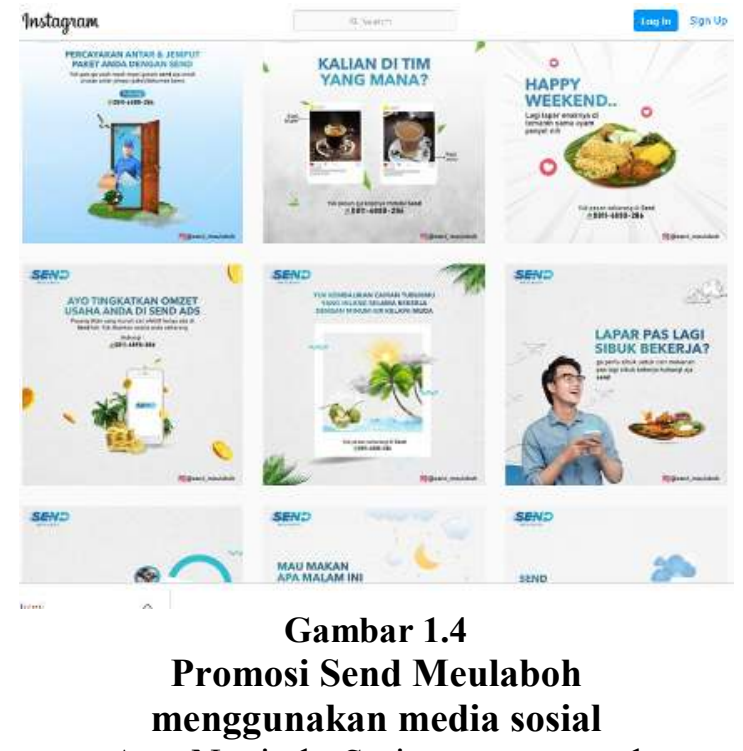

Ayu Novinda Sari sangat puas dengan pelayanan Send Meulaboh. Ia merupakan salah satu konsumen yang hampir setiap hari menggunakan semua jasa transportasi online yang ada di Aceh khususnya Meulaboh, menurutnya dari semua jasa transportasi online yang sudah ia gunakan di Aceh Barat, Send merupakan salah satu jasa transportasi online terbaik. Pelayanan cepat serta konsisten dalam menentukan harga walaupun seribet apapun pesanan konsumen Send tetap melayani dengan baik dan tidak ada perubahan harga. Harga menurut ayu tidak berpengaruh terhadap keputusan ia menggunakan Send karena menurutnya harga yang ditawarkan cukup sepadan dengan apa yang diterima, terutama jika memesan makanan harus menunggu lama dan mengantre, menggunakan jasa Send Meulaboh memudahkannya dalam banyak hal. Ayu mendapatkan informasi awal mengenai Send Meulaboh karena lokasi yang berada di dekat tempat tinggalnya, ia juga mengaku mendengar dari teman dekatnya mengenai harga yang ditawarkan Send murah dan praktis. $^{28}$ Senada dengan narasumber lainnya, Marfika Sari mengaku sangat puas menggunakan jasa Send. Harga menurutnya sangat berpengaruh terhadap ketertarikan penggunaan Send Meulaboh. Harga yang ditawarkan tidak terlalu mahal dan sesuai dengan kemampuan mahasiswa. Ia mengetahui Send Meulaboh melalui promosi yang lihat di media sosial. ia mengaku awalnya hanya mencoba saja namun merasa puas dan nyaman dengan pelayanan Send Meulaboh. Berdasarkan hasil wawancara, kelima narasumber mengaku sering menggunakan jasa Send Meulaboh ketika cuaca sedang tidak mendukung (hujan) atau berada pada kondisi jauh dari Kota. Send

\footnotetext{
${ }^{26}$ Aprilia Pratiwi dan Djawoto, Analisis Faktor Yang Mempengaruhi Keputusan Konsumen Dalam Memilih Grab-Car di Surabaya, Sekolah Tinggi Ilmu Ekonomi Indonesia (STIESIA) Surabaya, Jurnal Ilmu dan Riset Manajemen, Volume 6, Nomor 11, November 2017, hal, 4.

${ }^{27}$ Wawancara dengan Nedy Iswandi, Mahasiswa STAIN Teungku Dirundeng meulaboh Prodi Perbankan Islam, pada tanggal 10 Januuari 2020.

${ }^{28}$ Wawancara dengan Ayu Novinda Sari, pada tanggal 10-11 Januari 2020.
} 
Meulaboh menjadi alternatif terbaik untuk membantu meringankan aktifitas sehari-hari.

Berdasarkan hasil wawancara, menunjukkan Send memberikan pelayanan yang sangat baik dan memuaskan. Salah satu pointnya adalah Send Meulaboh merespon dengan sopan saat konsumen memesan makanan. Send juga sangat membantu apabila di antara salah satu konsumen sedang merasa tidak ingin keluar rumah atau mengalami kesulitan karena kendala cuaca, atau tidak memiliki kendaraan dan salah satu alternatif yang terpikir adalah menggunakan jasa Send Meulaboh.

Menurut dari kelima subjek diantaranya empat dari mereka menyatakan mengaku harga sangat berpengaruh terhadap keputusan menggunakan jasa Send karena harga yang ditawarkan murah dan terjangkau namun salah satu diantaranya mengaku harga yang diberikan cukup mahal disaat dia tidak berada diluar kota Meulaboh. Perusahaan menentukan harga relatif murah untuk meningkatkan minat konsumen agar menggunakan jasa Send. Promosi sangat berpengaruh terhadap keputusan penggunaan jasa Send. Promosi yang digunakan Send biasanya hari mulut-ke mulut, media sosial (Facebook, Instagram, Whatsapp). Selain itu, atribut Send Meulaboh seperti jaket yang terdapat logo Send serta memaparkan nomor WhatsApp pada jaket yang dikenakan juga merupakan alternatif promosi lainnya.

\section{F. KESIMPULAN}

Keputusan konsumen terhadap penggunaan jasa Send Meulaboh sangat ditentukan oleh kualitas pelayanan. Jadi, sistem control vendor (efisiensi, harga dan kualitas) dan stimulasi pemasaran (produk, harga dan promosi) terlihat sangat berkaitan erat dengan alasan penggunaan jasa Send Meulaboh. Harga sangat berpengaruh terhadap keputusan konsumen dalam menggunakan jasa Send Meulaboh karena harga yang ditawarkan oleh karena tergolong murah dan terjangkau terutama untuk mahasiswa. Selain itu, promosi sangat berpengaruh terhadap keputusan konsumen dalam menggunakan jasa Send Meulaboh. Karena dengan adanya promosi konsumen dapat mengetahui hadirnya Send di Meulaboh. Ketika membutuhkan jasa Send Meulaboh, para pelanggan tinggal memesan melalui nomor WhatsApp, sangat praktis, cepat dan mudah. Kemudahan tersebut juga merupakan point tambahan bagi konsumen dalam memutuskan menggunakan suatu layanan jasa. Meski demikian, Send Meulaboh masih memiliki kekurangan yaitu belum memiliki Aplikasi yang lebih memudahkan dan menjadikan Send Meulaboh menjadi ojek online setara atau lebih dari GoJek, Grab maupun jasa transportasi online lainnya.

\section{DAFTAR PUSTAKA}

\section{Buku}

Crosby, P. 1986. Quality Without Tear. Singapore: McGraw Hill

Kamus BesarBahasa Indonesia. 2008. Jakarta: Gramedia.

Fandi Tjiptono dan Gregorius Chandra, Pemasaran Global Konteks Offline dan Online, (Yogyakarta: UPP STIM YKPN), 2012.

Kotler, P dan Gary, A. 2008. Prinsip-prinsip Pemasaran. Jakarta: Erlangga.

Kotler, P dan Kevin, 1. 2009. Manajemen Pemasaran. Jakarta: Erlangga.

Kotler. 1997. Marketing Management: Analysis, Planning, Implementation and Control. New Jersey: PrenticeHall Inc. 
Lupiyoadi, $\mathrm{R}$ dan A. Hamdani. Nur'amna, S. 2018. Analisis Efektivitas Sales 2006.Manajemen Pemasaran Jasa. Jakarta: Salemba Empat.

Panjaitan, I. 2006. Pengaruh Pelayanan Dan Harga Pada Go-Jek Terhadap Kepuasan Konsumen Dengan Minat Sebagai Variabel Moderating. 19(2):44.

Pusat Bahasa Departement Pendidikan Nasional. 2005. Kamus Umum Bahasa Indonesia, Jakarta: Balai Pustaka.

Rulli Nasrullah. Media Sosial Perspektif Komunikasi, Budaya dan Sosioteknologi, (Bandung: Simbiosa Rekatama Media), 2016

Setiyaningrum, A, dkk. 2015. Prinsip-prinsip Pemasaran. Yogyakarta: Andi.

Sustina. 2003. Perilaku Konsumen Dan Komunikasi Pemasaran. Bandung: PT. Remaja Rosdakarya.

Swastha, B dan Irawan. 2003. Manajemen Pemasaran Modern. Yogyakarta: Liberty.

Tjiptono, F. 2001. Strategi Pamasaran. Yogyakarta: Andi Offset.

Umar, H. 2003. Metode Riset Perilaku Konsumen Jasa. Jakarta: Ghalia Indonesia.

Usmara, A. 2003. Strategi Baru Manajemen Pemasaran. Jogjakarta: Amara Books.

\section{Jurnal}

Aprilia Pratiwi Dan Djawoto, Analisis Faktor Yang Mempengaruhi Keputusan Konsumen Dalam Memilih Grab-Car Di Surabaya, Jurnal Riset Dan Manajemen, Sekolah Tinggi Ilmu Ekonomi Indonesia (Stiesia) Surabaya.

Muhammad Nasrullah, Islamic Branding, Religiusitas Dan Keputusan Konsumen Terhadap Produk, Jurnal Hukum Islam (Jhi), Volume 13, Nomor 2, Desember 2015, (79-87), Jurusan Syariah Dan Ekonomi Islam Stain Pekalongan.

Yohanes Suhari, Keputusan Membeli Secara Online dan Faktor-Faktor yang Mempengaruhinya, Jurnal Teknologi Informasi DINAMIK Volume XIII, No.2, Juli 2008: 140-146, Universitas Stikubank Semarang.

\section{Wawancara}

Wawancara dengan Ayu Novinda Sari, pada tanggal 10-11 Januuari 2020

Wawancara dengan Ilham Saputra, pada tanggal 10 Januuari 2020

Wawancara dengan Marfika Sari, pada tanggal 10-11 Januuari 2020

Wawancara dengan Nedy Iswandi, pada tanggal 10 Januuari 2020

Wawancara dengan Saidah, pada tanggal 10 Januuari 2020

\section{Sumber Website}

https://www.beacukai.go.id/berita/hadirihari-pers-nasional-bc-meulaboh.html diakses 29 Juni 2020

https://inet.detik.com/cyberlife/d3609781/awal-mula-transportasionline-menjamur-di-indonesia diakses pada 29 Juni 2020 
Instagram Send Meulaboh, Send Ojek Online and Delivery diakses pada 29 Juni 2020.

Whatsapp Send Meulaboh, Send Ojek Online and Delivery diakses pada 29 Juni 2020 .
Facebook Send Meulaboh, Send Ojek Online and Delivery diakses pada 29 Juni 2020. 